\title{
The Role of Local and Regional Factors in the Development of Creative Clusters
}

\begin{abstract}
Anna Szopa*
Creative industries tend to concentrate around large and medium cities forming creative local production systems. The article will present literature review focused on the role of creative cities in such aspects as: knowledge centers, entrepreneurship, financing, capital markets, infrastructure, cluster policy, government, presence of international companies, networks, and quality of life. The mini case study of Cracow city will provide better understanding of the factors that determine the development of creative clusters.
\end{abstract}

Keywords: creative industries, creative clusters, creative cities, location, creativity, policies, infrastructure.

Submitted: 28.08.2016 | Accepted: 07.11.2016

\section{Lokalne determinanty rozwoju klastrów przemysłów kreatywnych}

Celem artykułu jest przedstawienie wybranych determinantów rozwoju kreatywnych miast, takich jak: centra wiedzy, przedsiębiorczość, finansowanie, infrastruktura, polityki klastrowe, umiędzynarodowienie, sieci powiazań oraz jakość życia. Mini studium przypadku miasta Krakowa ma przyblizyć problematykę kreatywnych miast.

Słowa kluczowe: przemysły kreatywne, klastry kreatywne, kreatywne miasta, kreatywność, infrastruktura.

Nadesłany: 28.08.2016 | Zaakceptowany do druku: 07.11.2016

JEL: M13, M14

\section{Introduction}

There has been much debate over the nature of creative industries in cities around the world. The value placed on creative skills in the economy is illustrated by the concentration of creative jobs, creative industries, and their specific concentration - creative clusters. Creative industries are defined as "those which use creativity, cultural knowledge and intellectual property to produce products and services with social and cultural meaning" (UNESCO, 2005, p. 6). And in addition, by using the creative output, they remain important actors for the spread of creativity in the society. Creative industries have the ability to develop new products,

Anna Szopa, PhD - Jagiellonian University, Faculty of Management and Social Communication.

Mailing address: Jagiellonian University, Faculty of Management and Social Communication; ul. prof. Stanisława Łojasiewicza 4, 30-348 Cracow; e-mail: anna.szopa@interia.eu. 
provide a creative atmosphere encouraging flexible management systems, and offer a more rapid response to an external change. They bring together a community of "creative people" who share the same interest in novelty, but not necessarily in the same area, creating an environment that offers diversity and freedom of expression (Galloway and Dunlop, 2006).

From the economic point of view, creative industries are "industries which have their origin in individual creativity, skill and talent and which have a potential for wealth and job creation" (Department for Culture, Media and Sport, 2001). According to the Cultural times study, creative industries generate US\$2,250 billion of revenues and create 29.5 million jobs worldwide (EY, 2015). Furthermore, creative organizations are recognized as a source of innovation for the knowledge economy, providing a supply of new ideas for potential products across a range of industries and stand as a major source of competitiveness for cities (European Commission, 2012). Those initiatives abound especially in such areas as the inner city, historic quarters, sociocultural entertainment centers, multi-media and design districts or museum, music and theatre quarters (Evans, 2009). Such approach leverages professional network, promotes the exchange of experience and knowledge, and enhances professional association.

A wide literature has attempted to explain the general characteristics of creative industries; nevertheless, there is still little knowledge of the micro-interactions between the place and the creative clusters, especially factors that determine businesses launching within specific location and their development. This article will presented a literature review focused on the role of creative cities in such aspects as: knowledge centers, entrepreneurship, financing, capital markets, infrastructure, cluster policy, government, presence of international companies, networks, and quality of life; the mini case study of Cracow city will provide better understanding of determinant factors.

\section{Background}

The problem of regional development strategies that influences creative clusters was raised in 1998 in the first Creative Industries Mapping Document. Later on, researchers described creative clusters in scientific documents and national public policies (Chapain and Comunian, 2009). The relationship of each creative cluster with its location is a complex balance of factors. According to Allen J. Scott, who has been investigating the problem of creative fields, there exists an organic continuity between the place-specific features, the social and creative infrastructure and the industrial vocation of certain areas (Scott, 2006).

The problem of creative cities becomes critical for urban economy due to the fact that cities are nodes of the production of culture, art, and creativity in general. In addition, in creative industries, the relation between the creative attributes of places and the qualitative aspects of the final outputs is often evident (Scott, 2010). For the last two decades, economic strategies and policies have focused on specific assets and infrastructures which a city or a region should provide to enable it to become a creative city. The basic idea assumes that there should be a link to urban interventions. In this context, the place plays an important role in the development of creative cities as it ensures the necessary conditions for creativity and creative clusters (Florida, 2011).

\section{Determinant Factors of Creative Clusters}

A growing number of scientists, organizations, and policy makers are investigating the issue of what makes specific places successful in fostering and developing creative industries and creative economies. Chapain and Comunian, characterizing determinant factors of creative clusters, divided them into the macro level (comparing cities and their capabilities and labor market), meta level (analyzing the long-term impact of creative clusters as a knowledge economy), and micro level. At the same time, they noted that very limited attention was being paid to the mezo- and micro level (local policies). Later on, authors conducted research on the development of creative and cultural industries in England from a local and regional perspective and found out that policy makers place significant emphasis on the infrastructure, all while omitting such important factors as the lack 
of sustainability, network and social capital development. The authors recommend that, for a better understanding of the local and regional dimensions, they should be divided into four layers. The first layer describes relations between creative individuals and their surroundings, the second one relates to work opportunities that a place can offer, the third layer describes players engaged with the creative economy, and the fourth layer comprises the public support infrastructure (Chapain and Comunian, 2010).

According to professor Allan Barrell, nine factors determine the growth of creative clusters: knowledge centers, entrepreneurship, financing, capital markets, infrastructure, cluster policy, government, presence of international companies, networks, and quality of life (Barrell, 2016).

Knowledge centers - creative industries benefit from the location of organizations that are specialized since it enhances professional association and knowledge exchange (Cook et al., 2007). In such agglomerations, knowledge is created and shared more efficiently at local proximity, firms based on a combination of existing knowledge have a high propensity to cluster over space. Arora, Florida, Gates, Grand and Kamlet emphasize that the location of well-educated societies and the infrastructures necessary for their formation (higher schools and other educational institutions) play a fundamental role in the performance of creative companies, especially for those where individuals with high levels of human capital constitute a primary input to the production process (Arora et al., 2000).

Entrepreneurship - results in a convergence result, the presence of complementary economic activity creates externalities that enhance incentives and reduce barriers for new businesses. Creative clusters are perceived as privileged places for entrepreneurial activities because of the presence of informality in the economic transactions of co-located actors that are facilitated by their proximity. Economic relations are socially embedded in a specific local context that depends upon institutions, procedures, and a set of assumptions shared by actors belonging to the same social place (Hunnings and Thompson, 2017).

Network - in building a strong network an important role is played by trust since it reinforces stable interactions; it is perceived as a result of continuous interactions. The National Endowment for Science, Technology and the Arts claims that networks determine the connection to new sources of knowledge and market opportunities due to the fact that they pull together actors to share ideas, resources, and maintain strategic investments The importance of networks as a soft infrastructure fostering economic development has recently been introduced at the policy level, with varying degrees of success (NESTA, 2014).

Infrastructure - investment in infrastructure is widely regarded as promoting socio-economic growth, since it has a critical and often irreversible role in the development process. Components such as the local availability of business spaces, transport services, and telecommunication improve the productivity of inputs in the production process, and thus strengthen long-run clusters' growth performance. The capacity has generally been shown to attract more firms to a region rather than the reverse, leading to more jobs. Alternatively, firms which are located in these cities for other reasons will find it easier to introduce new products and processes because of a more developed local support infrastructure (Guy et al., 2001).

Financing and capital markets - creative clusters have traditionally been funded with public money to pursue sociocultural purposes; however, policy makers are increasingly promoting a greater use of private resources, the financing of creativity is moving towards public-private partnerships models where venture capital, tax deductions, direct public subsidies, or bank guarantees support creative clusters (KEA, 2010). Such improvement of the efficiency of capital allocation allows for better risk-sharing and improves the availability of long-term financing, enabling companies to better manage interest rates and maturity risk associated with long-term investments. Furthermore, when capital markets opened to foreign investments, financial integration increased as foreign capital was attracted, and the cost of capital for local firms lowered (Wagner, 2011).

Presence of international companies a more extensive network with internationally experienced companies enables the companies to acquire knowledge through 
interaction with the market, establish new relationships and network positions through e.g. joint ventures, strengthened information channels, and provide access to important resources. Being a member of a cluster adds greater value and creates more opportunities to grow and expand abroad (Kowalski, 2014).

Cluster policy - national and regional authorities have started to see creative industries as important elements of the economic performance of territories and thus have started supporting creative initiatives through industrial policies. Cluster policy initiatives have been used in several European countries as a platform to increase innovation and thus to contribute to sustainable growth (Selada et al., 2010). Moreover, in addition to modifying its own policies and practices, the government can motivate, facilitate, and provide incentives for collective action by the private sector. Creative businesses connect to and interact with local and regional levels of governance but also affect and engage with national and international actors (Porter, 2000).

Government - government policy based creative clusters as a collection of instruments and measures used by the authorities at various levels to enhance its competitiveness by stimulating, developing them mainly at the regional level. It supports creative clusters by developing the business environment, providing infrastructure and services, promoting business and networking between enterprises, building community, evaluating and improving the policies and programs (Brodzicki, 2010)

Quality of life - creative clusters are important elements to attract and retain highly skilled personnel, which tend to be extremely mobile. Residential or worker amenities are exogenous goods or services that could increase the attractiveness, value, or comfort of a specific place. Therefore, such features of creative industry clusters as the existence of cultural infrastructure, presence of "soft" factors, access to gatekeepers, location artists and creative class, existence of a particular identity, and a place brand and image should play a crucial role in the development of creative clusters (Turok, 2003).

Even though the importance of local, regional determinants for the development of creative clusters is often emphasized by researchers and policy makers, the report on creative clusters in Europe shows the lack of comprehensive activities that might reinforce the process of growth of creative clusters.

\section{Enabling Creative Activities: the Role of Local Determinants in Cracow}

The aim of this part of the paper is to present creative clusters in Cracow and shed some light on local factors that determine their activities. The author reviewed existing reports, municipal documents, and programs such as: World Investment Report, Development Strategy of Southern Poland until 2020, European Strategic Cluster Partnerships, UNESCO Creative Cities Network, as well as data available at the Statistical Office in Cracow. As one of the best known historic cities in the world, famous for its architecture and cultural traditions, Cracow - which has for centuries been considered the cultural and creative capital of Poland and at present remains one of the country's most important creative cities - seems particularly well-suited for a mini case study.

\section{Cracow's Creative Clusters}

Two creative clusters operate in Cracow, namely Krakow Film Cluster and Cluster of Culture and Free Time Industries (INRET). The Krakow Film Cluster is an association of professional companies, organizations, and experienced individuals that operate in the film industry; the Cluster brings together over 300 representatives. It is also a platform for cooperation, exchange of information as well as promotional, educational and innovation-supporting actions (Krakowski Klaster Filmowy, 2016). The Cluster of Culture and Free Time Industries (INRET) is an organization supporting the process of creating and developing products and services of creative industries. The Cluster combines the resources with the needs for the effective use of opportunities associated with the development of an economy based on creativity and knowledge. INRET pursues its activities by using the following tools: ECON - trainings, conferences, and workshops, Bize - Internet platform, and Hubee - business incubator (INRET, 2016). 
Moreover, Cracow has a couple of unique groupings of activities linked with creativity, designed within larger urban places. The most popular is Zabłocie - an area of Old Podgórze with good accessibility and green leisure spaces that attract mainly artists and freelance professionals. Zabłocie provides a broad spectrum of artistic, entertainment, and cultural activities with artistic cafés, restaurants, galleries, and museums (Museum of Contemporary Art in Cracow, Museum of Tadeusz Kantor, Schindler's Factory). It has also started to play a more significant role as a place of artistic education with three music schools, the Cracow School of Art and Fashion Design, and A.F. Modrzewski University that offers degrees in interior design, architecture and urban planning, journalism and communication, cultural studies, painting, and television and film production; it also runs post-graduate courses in journalism and media, and the art and antiques market (Zabłocie, 2016) Kazimierz and Nowa Huta districts play a similar role as Zabłocie.

\section{The Role of Local Determinants}

Cracow is one of the most important metropolitan cities in Poland and has traditionally been the focus of cultural and creative activities. In 1978, by the decision of the UNESCO World Heritage Committee, Cracow was inscribed on the first list of the most valuable sites in the world (UNESCO World Heritage Site list, 2016). In 2000, the city was honored with the title of the European Capital of Culture for that year, with an array of cultural events featuring literature, theatre, music, and folk traditions taking place throughout the year. In recent decades, however, its position has been increasingly challenged not only by the dispersion of some creative endeavors into other areas of the city, but also by the emergence of new significant areas of concentration of creative activities. An important promotional role in its development is played by the Creative Cities Network under the patronage of UNESCO. This network promotes socioeconomic initiatives through creative industries and helps create a healthy urban environment. In the group of 40 member cities, there is only one Polish city - Cracow - designated as the city of literature
(UNESCO Creative Cities Network, 2016). Cracow's historic physical setting, its accessibility and walkability are key in understanding Cracow's cultural position. Centered around the Renaissance Grand Square (Rynek Główny), the largest plaza of medieval Europe with the Cloth Hall (Sukiennice) at its heart, it is precisely the kind of environment urban designers are trying to retrofit. It makes being convivial and networking easy. Also, public transport is based on a fairly dense network of tram and bus lines operated by a municipal company, supplemented by a number of private operators. Local trains connect most of the suburbs. Cracow also has an international airport (Miejska struktura, 2016). Cracow is the second largest city in Poland, in 2015 its population was 761 069. It is a major center of education in Poland. Twenty-three institutions of higher education offer courses to 178807 students, accounting for $25 \%$ of Cracow's population - Cracow remains at its core a potential knowledge city (Statistical Office in Krakow, 2016). In addition, there are about 50 large multinational companies in the city. Foreign direct investment in Cracow has reached approximately USD 3.5 billion. The city has been trying to position itself as Europe's Silicon Valley, based on the large number of local and foreign hi-tech companies (UNCTAD, 2011). The City of Cracow supports such initiatives as Apps4Krk, Małopolska Information Technology Park MPTI, Krakow Living Lab and Watify that are examples of Smart City initiatives strengthening and enriching the Development Strategy of Cracow 2014 - 2020 and the Regional City Strategy, with emphasis on the Regional Innovation Strategy as the operational act (Development Strategy of Southern Poland until 2020, 2014). The most important role in this process is played by Krakow Technology Park which is one of the key actors in co-creating, implementing, and promoting cluster initiatives. Krakow Technology Park collaborates very actively with regional and local governments, universities, NGOs, the business sector, and the local community, at the time when straight conversation and new approaches are needed to stimulate economic development and implement innovations (Krakowski Park Technologiczny, 2016). Creative clusters in Cracow benefit from 
being members of the European Strategic Cluster Partnerships - Going International, labelled by the European Commission, DG Growth, and the Executive Agency for SMEs of the European Commission. The aim of this partnership is to develop and implement a joint internationalization strategy and support. Partnership represents a potential to support more than 17000 European SMEs in accessing global value chains and taking a leading position globally (European Strategic Cluster Partnerships, 2016). Cracow's creative clusters have a wide range of possibilities when applying for financial support, including traditional forms of financing (such as for example a loan) and new ones (e.g. seed capital or crowdfunding). The study on Polish creative clusters shows that cluster managers tend to apply for public national and EU programs and take advantage of seed capital, venture capital, business angels, and crowdfunding (Szultka, 2012).

Although the mini case study explores positive aspects of a creative city, the European Cluster Observatory reports show that the number of creative clusters in Poland is inadequate in relation to the potential of the Polish economy; in addition, data show that businesses are still in the growth phase (European Cluster Observatory, 2016). This situation might be determined by Polish administrative or legal barriers (e.g. Public Finance Act that prohibits public institutions in the R\&D sector from investing in a venture business), limited national expenditures on $\mathrm{R} \& \mathrm{D}$, fractional financing in comparison to other sectors, leading in consequence to insufficient research on creative clusters in Poland that influences strategies and policy interventions, assets and infrastructure which a city or a region should provide to a creative city.

\section{Conclusion}

Creative clusters present a new type of national, regional, and local economic picture, and they require new roles of companies, governments, and other institutions. Therefore, they are becoming relevant, governments implement policies aiming at facilitating the emergence of clusters as well as at supporting existing clusters. Clusters enhance innovation processes and tend to be the economic leaders of our age; have high concentrations of highly skilled class, advanced infrastructure, and present practices that facilitate collective action. Such places show strong signs of overall local vitality, such as an increase in regional growth and employment. The creative environment of these cities - with their concentrations of designers, artists, and specialists in both new content production and commercialization, would create conditions for the emergence of innovative businesses and attract firms hoping to develop new products.

The paper contributes to the understanding of the role of the local factors that determine the development of creative clusters, suggesting that the physical aspects of a place are meaningful to its creative production. The presented mini case of Cracow explores the potential to develop creative clusters. The location of Cracow, coupled with its good transportation system and infrastructure, also makes the city very attractive. In addition, the presence of historic authenticity in a place contributes to the creation of an appropriate urban location that favors creative minds, and combined university assets create good conditions for the development of creative industries. Local knowledge centers and informal networks play a crucial role in connecting creators with each other and with their local and regional markets. Furthermore, informal networks guarantee a flow of ideas as well as the fulfillment of the need for structural advice and business support.

Processes of creative clusters development have been enhanced by government interventions in the form of support programs, and local and regional actors have put more emphasis on providing business support to creative individuals and companies. The article suggests local enabling factors that could be addressed by national policies. This is especially important as, despite years of implementation of regional policies in Poland, the process of clustering is still at the development stage. The presented article can be a starting point for devising methods to understand how local and regional dynamics of creative industries contribute to the national development of such industries. 


\section{References}

Arora, A., Florida, R., Gates, G. J. and Kamlet, M. (2000). Human capital, quality of place, and location. Working Paper. H.J. Heinz III School of Public Policy. Pittsburg: Carnegie Mellon University. Retrieved from: https:/www.researchgate.net/ publication/250681787_Human_Capital_Quality_ of_Place_and_Location (19.07.2016).

Barrell, A. (2016). The Cambridge phenomenon Presented during the Innovation Forum, Cracow.

Brodzicki, T. (2010). Critical review of cluster mapping studies in Poland. Analizy i Opracowania Katedry Ekonomiki Integracji Europejskiej Uniwersytetu Gdańskiego. Retrieved from: http:/gnu.univ. gda.pl/ keie/aio17.pdf (04.08.2016).

Chapain, C. A. and Comunian, R. (2009). Enabling or inhibiting the creative economy: The role of the local and regional dimensions in England. Working Paper. Retrieved from: http://www.egrg.rgs.org/wp-content/uploads/2014/02/egrg wp0309-Chapain-Comunian.pdf (08.03.2016)

Cooke, P., De Laurentis, C., Tödtling, F. and Trippl, M. (2007). Regional knowledge economies. Markets, clusters and innovation. Cheltenham: Edward Elgar. Retrieved from: https://books.google.pl/books?id= bkm-uW3TdP4C\&printsec $=$ frontcover $\& d q=$ Reg onal + Knowledge + Economies $\&$ hl $=$ pl $\& s a=X \&$ edir esc $=\mathrm{y} \# \mathrm{~V}=$ onepage $\& \mathrm{q}=$ Regional $\% 20 \mathrm{Know}-$ ledge $\% 20$ Economies $\& \mathrm{f}=$ false.

Department for Culture, Media and Sport. (2001). Creative industries mapping document. London Department for Culture, Media and Sport. Retrieved from: https://www.gov.uk/government/publications/creative-industries-mapping-documents-2001 (03.06.2016).

Development strategy of southern Poland until 2020. (2016). Retrieved from: https://www.mr.gov.pl/ media (20.07.2016)

European Cluster Observatory. (2016). Retrieved from: http://ec.europa.eu/growth/smes/cluster/observatory/ (20.08.206).

European Commission. (2012). Materials research and innovation in the creative industries. Report on round table discussions. Brussels: European Commission. Retrieved from: https:/ec.europa. eu/research/industrial_technologies/pdf/materials-in-creative-industries-report_en.pdf (09.04.2016).

European Strategic Cluster Partnerships. (2016) Retrieved from: http://www.clustercollaboration.eu/ eu-cluster-partnerships (12.08.2016).

Evans, G. (2009). Creative cities, creative spaces and urban policy. Urban Studies, 46(5-6), 1003 1040, http://dx.doi.org/10.1177/0042098009103853. EY. (2015). Cultural times: The first global map of cultural and creative industries. London: EY. Retrieved from: http:/www.ey.com/Publication (02.07.2016).
Florida, R. (2011). Narodziny klasy kreatywnej. Warszawa: Narodowe Centrum Kultury.

Galloway, S. and Dunlop, S. (2006). Deconstructing the concept of ,Creative Industries'. In: Ch. Eisenberg, R. Gerlach and Ch. Handke (eds.), Cultural industries: The British experience in international perspective (pp. 33-63). Berlin: Humboldt University Berlin. Edoc-Server. Retrieved from: http://edoc. hu-berlin.de (10.08.2016).

Guy, S., Marvin, S. and Moss, T. (2001). Urban infrastructure in transition. Networks, buildings, plans. Earthscan Publication. Retrieved from: https://books.google.pl/books?id=irUoDAAAQ $\mathrm{BAJ} \&$ printsec $=$ frontcover $\& \mathrm{hl}=\mathrm{pl} \&$ source $=\mathrm{gbs}$ ge_summary_r $\&$ cad $=0 \# \mathrm{v}=$ onepage $\& \mathrm{q} \& \mathrm{f}=$ false. Hunnings, R. and Thompson, P. (2017). A network theory of regional competitiveness: Innovation, entrepreneurship and growth. In: R. Hunnings and P. Thompson, Handbook of regions and competitiveness. Cheltenham: Edward Elgard. Retrieved from: https://books.google.pl/books? id=0HdHD gAAQBAJ $\& p g=$ PA161 $\& 1 p g=$ PA161 $\& d q=$ Delga do + et.al., $+2010+$ creative $\&$ source $=$ bl\&ots $=u W 7$ 4fZG9H\&sig $=$ aCZedY7LbcZYcJUF oTXFEM$\bar{z} 62 \mathrm{M} \& \mathrm{hl}=\mathrm{pl} \& \mathrm{sa}=\mathrm{X} \& \mathrm{ved}=0 \mathrm{ahUKEw} \overline{\mathrm{i}} \mathrm{H}-\mathrm{fbRi}$ zzT AhUjEJoKHSz5AggQ6AEIMjAB\#v=onepage \& $\mathrm{q}=$ Delgado $\% 20$ et.al. $\% 2 \mathrm{C} \% 202010 \% 20$ creative$\& \mathrm{f}=$ false $(20.08 .2016)$.

INRET. (2016). Cluster of Culture and Free Time Industries. Retrieved from: http://www.inret.pl (08.12.2016).

KEA. (2010). Promoting investment in the cultural and creative sector: Financing needs, trends and opportunities. Retrieved from: http://www.keanet. eu (08.06.2016)

Kowalski, A.M. (2014). The role of innovative clusters in the process of internationalization of firms. Journal of Economics, Business and Management, 2(3), 181-185. Retrieved from: http://www.joebm. com/papers/121-L00009.pdf.

Krakowski Klaster Filmowy. (2016). Retrieved from: http://www.film-krakow.pl (20.07.2016).

Krakowski Park Technologiczny. (2016). Retrieved from: http://www.kpt.krakow.pl (16.08.2016).

Miejska struktura. (2016). Retrieved from: mi.krakow.pl (16.07.2016).

NESTA. (2009). De Propris, L., Chapain, C., Cooke, P., MacNeill, S. and Mateos-Garcia, J. The geography and creativity. London: NESTA. Retrieved from: http://www.creativespace.at/sites/default/ files/en (04.07.2016).

NESTA. (2014). Networks of innovation. Retrieved from: http://www.nesta.org.uk/blog/networks-innovation (09.08.2016)

Porter, M. (2000). Location, competition, and economic development: Local clusters in a global economy. Economic Development Quarterly, 14(1) 
Retrieved from: home.furb.br/wilhelm/COMPETIV/Porter_Cluster3.doc.

Scott, A. J. (2006). Creative cities: Conceptual issues and policy questions. Journal of Urban Affairs, 28(1), 1-17. Retrieved from: http:// www.tandfonline.com/doi/full/10.1111/j.0735 $-2166.2006 .00256 . x$ ? scroll $=$ top\&needAccess $=$ true (08.04.2016)

Selada, C., Vihena da Cunha, I. and Tomás, E. (2010). Creative clusters in low density urban areas: A case study approach. Presented at ERSA conference. Retrieved from: http://s3.amazonaws.com/ academia.edu.documents (04.05.206).

Statistical Office in Krakow. (2016). Retrieved from: http://www.bip.krakow (07.08.2016).

Szultka, S. (2012). Klastry w sektorach kreatywnych motory rozwoju miast. Warszawa: PARP.

Turok, I. (2003). Cities, clusters and creative industries: The case of film and television in Scotland. European Planning Studies, 11(5), 549-56. Retrieved from: http://nknu.pbworks.com/f/Cities, $+\mathrm{Clu}-$ sters + and + Creative + Industries.pdf.
UNCTAD. (2011). World investment report. Retrieved from: http://unctad.org/en/PublicationsLibrary/ wir2011_en.pdf (20.08.2016).

UNESCO Creative Cities Network. (2016). Retrieved from: https://en.unesco.org/creative-cities (12.06.2016).

UNESCO Creative Cities Network. (2016a). Retrieved from: http://en.unesco.org/creative-cities/ home (21.08.2016).

UNESCO. (2005). Convention on the protection and promotion of the diversity of cultural expressions. Paris: UNESCO. Retrieved from: http://portal.unesco.org/en/ev.php (15.08.2016).

UNESCO World Heritage Site list. (2016). Retrieved from: http://whc.unesco.org (20.08.2016).

Wagner, L. (2011). Entrepreneurship in the creative industries: An international perspective. New England Journal of Entrepreneurship, 14(1). Retrieved from: http://digitalcommons.sacredheart.edu (08.06.2016)

Zabłocie. (2016). Retrieved from: http://www.zablocie.com (14.08.2016). 